\title{
Factors controlling benzo(a)pyrene concentration in aerosols in the urbanized coastal zone. A case study: Gdynia, Poland (Southern Baltic Sea)
}

\author{
Marta Staniszewska • Bożena Graca • \\ Magdalena Bełdowska • Dominika Saniewska
}

Received: 28 June 2012 / Accepted: 8 November 2012 / Published online: 18 December 2012

(C) The Author(s) 2012. This article is published with open access at Springerlink.com

\begin{abstract}
Annual study on the benzo(a)pyrene (BaP) concentration in aerosols in the coastal zone of the Gulf of Gdansk (southern Baltic) has been performed at Gdynia station. Combustion processes, especially domestic heating of both local and regional origin, were identified as the main sources of benzo(a)pyrene in this area. Concentrations observed during the heating season (mean $2.18 \mathrm{ngm}^{-3}$ ) were significantly higher than these recorded in the non-heating season (mean $0.05 \mathrm{ngm}^{-3}$ ). High benzo(a)pyrene concentrations were associated with low temperature and high humidity. Whereas high levels of precipitation usually decreased the BaP concentration in aerosols. The concentration of this factor in the studied area depended also on the wind direction and air masses trajectories. During heating season, continental air masses (coming from S, SE, SW) seemed to increase benzo(a)pyrene concentration, while maritime air masses (from N, NE, NW) caused its decrease. The differences in the $\mathrm{BaP}$ concentration resulting from potentially different emission levels of this compound during working and non-working days were not clearly pronounced.
\end{abstract}

Keywords Benzo(a)pyrene · Aerosols · The Gulf of Gdansk coastal zone · Gdynia

Responsible editor: Gerhard Lammel

M. Staniszewska $(\bowtie) \cdot$ B. Graca $\cdot$ M. Bełdowska $\cdot$ D. Saniewska Department of Marine Chemistry and Environmental Protection, Institute of Oceanography, University of Gdansk, Al. Marszałka Piłsudskiego 46,

81-378 Gdynia, Poland

e-mail: marta.staniszewska@ug.edu.pl

\section{Introduction}

Benzo(a)pyrene $(\mathrm{BaP})$ is the major indicator of the pollution by the polycyclic aromatic hydrocarbons (PAHs). It has been identified by International Agency for Research on Cancer (IARC) as a class 1 carcinogen (i.e., carcinogenic to humans). The transformation products of $\mathrm{BaP}-$ i.e., peroxides, quinones, sulfur, and nitric derivatives - are also harmful to living organisms (Papageorgopoulou et al. 1999; Chetwittayachan et al. 2002).

$\mathrm{BaP}$ concentration in a given area is a function of anthropogenic activity and climate (Papageorgopoulou et al. 1999; Chetwittayachan et al. 2002; Ravindra et al. 2008). This compound enters the environment as a product of incomplete combustion processes. In the case of urban areas, the main sources of BaP (so-called "low emission") are coal and wood domestic heating as well as transport-related emissions (petrol combustion, tarmac, and tire wear; Tao et al. 2007; Ravindra et al. 2008). Other significant sources of benzo(a)pyrene are heavy industry, factories, coke, and electric plants, combined heat and power plants, uncontrolled fires, and waste incineration (Ravindra et al. 2008).

After ingestion, air can be the second-most important human exposure pathway for BaP. Because of its high hydrophobicity and volatile, this compound is usually adsorbed onto particles (soot and dust) that are present in the atmosphere. In such form, BaP, as well as the other PAHs, can penetrate the respiratory system. Especially dangerous are $\mathrm{BaP}$ adsorbed on particles of diameters below 1-2 $\mu \mathrm{m}$ (PM1, PM2.5). They can enter pulmonary alveoli and then the particle-bound substances can reach the circulatory system 
and vital organs. Larger particles (PM10 and bigger) can also enter human organism, where adsorbed to them toxic compounds can be released, especially inside the gastrointestinal tract (Chetwittayachan et al. 2002; Halek et al. 2006).

In the EU countries, the quantitative measurements of $\mathrm{BaP}$ concentration in PM10 are performed within the frame of 2004/107/WE directive. Based on these measurements, the annual average value of $\mathrm{BaP}$ concentration in the air is computed. However, this information is insufficient to improve our knowledge about long and short term variability of $\mathrm{BaP}$ as well as the factors impacting this variability. Up to $95 \%$ of total PAHs concentration might be associated with fine particles $(<3 \mu \mathrm{m})$ and only a few percent of $\mathrm{BaP}$ is associated with aerosols larger than $11 \mu \mathrm{m}$ (Sheu et al. 1997; Zhou et al. 2005; Ji et al. 2007; Ravindra et al. 2008). Nevertheless, significantly higher cytotoxicity (with comparable genotoxicity) of total suspended particulates fraction than the PM10 fraction in urban areas has been observed (Fabiani et al. 2008). Moreover, epidemiological studies confirmed relationships between the concentration of toxic respirable dusts and the frequency of cancer cases (i.e. lung cancer). Toxicity correlated well with the content of $\mathrm{BaP}$ and the other PAHs (Nielsen et al. 1996; Jung et al. 2010).

The aim of this study was to characterize the concentrations of atmospheric $\mathrm{BaP}$ in the urbanized coastal zone of the Gulf of Gdansk and identification of major factors controlling the variability of $\mathrm{BaP}$ concentrations in such kind of environments.

\section{Studied area}

Gdynia, where the investigation was performed, is a harbor city with significant tourism and recreational activities located at the coast of the Gulf of Gdansk (Baltic Sea, Poland; Fig. 1). Together with Sopot and Gdansk, it forms the metropolitan agglomeration called Tricity. The area of Gdynia equals $135 \mathrm{~km}^{2}$ and its population is 250,000 (Statistical Yearbook 2008).
Fig. 1 Location of Gdynia (the sampling place)

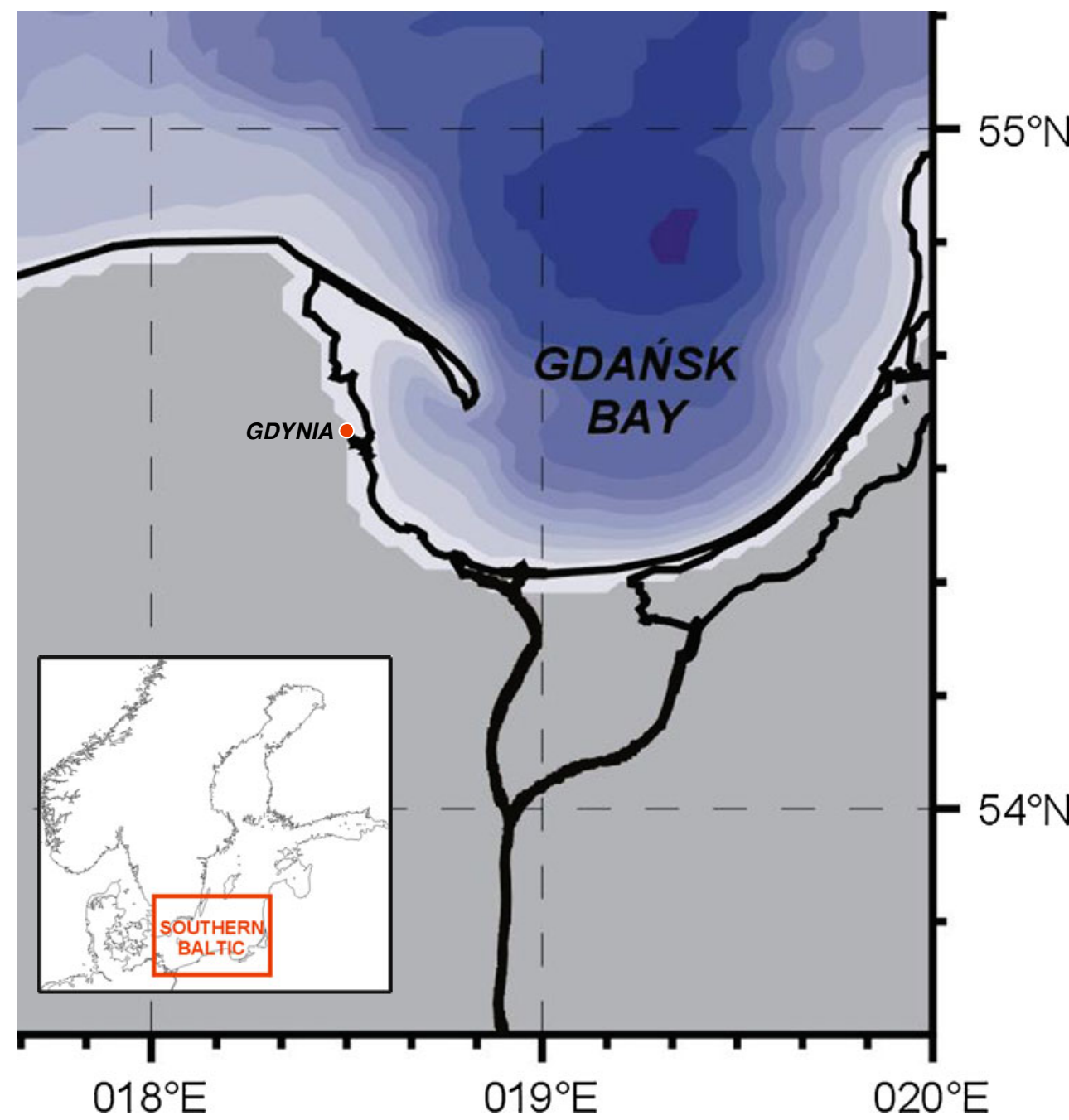


Potential sources of $\mathrm{BaP}$ in Gdynia are power and heating plants, the industry, incineration plants for oily and hospital wastes as well as paint pyrolysis plants. The level of the air pollution in Tricity is also influenced by the households that use domestic coal heating (ca. $8 \%$ ) and intensive car traffic (Statistical yearbook 2008).

\section{Material and methods}

Aerosol samples were taken between 17.XII.2007 and 17.XII.2008 in the centre of Gdynia, ca. $500 \mathrm{~m}$ from the coast, at the height of $30 \mathrm{~m}$ (on the roof of the Institute of Oceanography Building). Aerosols were collected on ignited glass fiber filters (pore size of $0.4 \mu \mathrm{m})$, placed in a Teflon holder connected to a vacuum pump with the mean flow rate of $0.8 \mathrm{~m}^{3} \cdot \mathrm{h}^{-1}$. Filters were changed under a laminar flow hood thrice a week - on Monday (sampling time from Friday to Monday), Wednesday (sampling time from Monday to Wednesday), and Friday (sampling time from Wednesday to Friday). The samples were kept frozen until the analysis $\left(-20{ }^{\circ} \mathrm{C}\right)$.

The isolation of $\mathrm{BaP}$ from the collected samples was conducted by means of solvent extraction $\left(4 \mathrm{~cm}^{3}\right.$ acetonitrile: dichloromethane 3:1 v/v) in an ultrasonic bath (time, $10 \mathrm{~min}$; extraction temperature $21^{\circ} \mathrm{C}$; Periera et al. 2001; Halek et al. 2006).

$\mathrm{BaP}$ concentration was determined with the use of liquid chromatography with a fluorescence detector (excitation, $\lambda=296 \mathrm{~nm}$; emission, $\lambda=408 \mathrm{~nm}$ ). The chromatographic separation was performed using Nucleosil column (100-5 C18 PAH, $250 \mathrm{~mm} / 4.6 \mu \mathrm{m})$ and mobile phase gradient acetonitrile: water. The recovery of $\mathrm{BaP}$ in reference to the certified material (SRM-2585) amounted to $83 \%$. The detection limit of the method was determined to be $0.01 \mathrm{ng} \mathrm{m}^{-3}$.

During this study the meteorological conditions ( $\mathrm{T}$ - air temperature, $\mathrm{V}$-wind speed, $\mathrm{B}$-wind direction, $\mathrm{R}$ amount of precipitation, $\mathrm{W}$ - relative humidity, and $\mathrm{P}$ - atmospheric pressure) were recorded continuously by the HUGER WEATHER STATION. Forty-eight-hour air-mass backward trajectories at $6 \mathrm{~h}$ intervals, at 20,500, and $1,000 \mathrm{~m}$ above the starting point located at $20 \mathrm{~m}$ a.g.1., were calculated by NOAA HYSPLIT MODEL were taken from GDAS Meteorological data (http://www.arl.noaa.gov/ ready.html).

Statistical analysis was performed using Statistica 8.0 software. Apart from basic statistics, Mann-Whitney $U$ tests, Kruskal-Wallis ANOVA, principal components analysis, and cluster and regression analyses were used. The significance level $(p)$ in the hypothesis tests for all analyses was $<0.05$.

\section{Results and discussion}

Meteorological conditions

Meteorological conditions characterizing the sampling period (17.XII.2007-17.XII.2008) are presented in Table 1. Average annual temperature in Gdynia in 2008 was $+10.6{ }^{\circ} \mathrm{C}$. It means that the year 2008 was one of warmest years in this decade, what resulted in shorter than average heating season (Szymanska et al. 2008). The coldest was December 2008 whereas the warmest was July 2008. The lowest relative humidity was recorded in spring/summer (May/June) 2008, whereas the highest values were observed in winter. Maximum wind speeds were noted in winter, especially in February $2008\left(>4 \mathrm{~m} \cdot \mathrm{s}^{-1}\right)$. In most of the cases (91\% of data), precipitation did not exceed $13.2 \mathrm{~mm}$. Relatively high precipitation $(28.6-92 \mathrm{~mm})$ occurred between December 2007 and May 2008 as well as in November 2008.

Benzo(a)pyrene concentration in aerosols

An annual average concentration of benzo(a)pyrene in aerosols in the studied area exceeded the value $\left(1 \mathrm{ng} \mathrm{m}^{-3}\right)$ acceptable for the EU countries (Directive 2004/107/WE; Table 2). At the same time, a clear seasonality (Table 2) and large intra-monthly variability (Fig. 2) of benzo(a)pyrene concentration were observed. During the heating season (17.XII.07-30.IV.08; 1.X.08-17.XII.08) both average and median concentrations clearly exceeded the values observed in the non-heating season (1.V.08-30.IX.08) (Table 2). Over the most of the heating season, the benzo(a)pyrene concentration was higher than $1 \mathrm{ng} \mathrm{m}^{-3}$. But actually there is no reference point to our results. The ambient air quality standards determine only the value of the acceptable annual average benzo(a)pyrene concentration. The utility of such an indicator seems to be questionable considering continuous exposure to high concentrations within a few months of the year. Therefore, determination of the acceptable daily or monthly average concentration of benzo(a)pyrene would be very valuable.

Table 1 Meteorological condition during measurements performed in Gdynia (17.XII.2007-17.XII.2008)

\begin{tabular}{llll}
\hline Variable & Average & Min. & Max. \\
\hline Air temperature $\left({ }^{\circ} \mathrm{C}\right)$ & 10.6 & -4.3 & 23.1 \\
Wind speed $\left(\mathrm{m} \cdot \mathrm{s}^{-1}\right)$ & 2.2 & 0.0 & 5.1 \\
Amount of precipitation $(\mathrm{mm})$ & 5.2 & 0.0 & 92.5 \\
Relative humidity $(\%)$ & 71.8 & 45.1 & 93.4 \\
Atmospheric pressure (mbar) & 1,009 & 981 & 1,034 \\
\hline
\end{tabular}


Table 2 Basic statistics of BaP concentrations $\left(\mathrm{ng} \mathrm{m}^{-3}\right.$ ) in aerosols during measurements performed in Gdynia (17.XII.2007-17.XII.2008)

\begin{tabular}{|c|c|c|c|c|c|}
\hline \multirow[t]{2}{*}{ Variable } & \multicolumn{5}{|c|}{ Sampling period } \\
\hline & $\begin{array}{l}\text { (17.XII.07- } \\
\text { 17.XII.08) }\end{array}$ & $\begin{array}{l}\text { (17.XII.07-30.IV.08; 1.X.08- } \\
\text { 17.XII.08) heating season }\end{array}$ & $\begin{array}{l}\text { (1.V.08-30.IX.08) } \\
\text { non-heating season }\end{array}$ & Weekends & Workdays \\
\hline $\begin{array}{l}\text { Number of } \\
\text { measurements }\end{array}$ & 153 & 89 & 64 & 58 & 94 \\
\hline $\begin{array}{l}\text { Average } \\
\text { concentrations } \pm \\
\text { standard deviation }\end{array}$ & $1.29 \pm 2.75$ & $2.18 \pm 3.33$ & $0.05 \pm 0.09$ & $1.94 \pm 4.72$ & $0.91 \pm 1.51$ \\
\hline Min.-max. & n.d. -25.20 & $0.11-25.20$ & n.d. -0.36 & n.d. -25.20 & n.d. -8.26 \\
\hline $\begin{array}{l}\text { Median } \\
\text { concentrations }\end{array}$ & 0.34 & 1.10 & $<$ LOD & 0.52 & 0.30 \\
\hline $\begin{array}{l}\text { (Lower-upper } \\
\text { quartile) }\end{array}$ & $<$ LOD -1.25 & $0.52-2.36$ & $<$ LOD -0.07 & $0.06-2.05$ & $<$ LOD -1.22 \\
\hline
\end{tabular}

$L O D$ limit of detection

Some difficulty in comparison of the obtained results with other studies is the fact that mostly they report the average values. However, positive skewness of results distribution and the outlying values are likely to lead to an overestimation of averages. In presented study $93 \%$ of $\mathrm{BaP}$ concentration level did not exceed $4 \mathrm{ng} \cdot \mathrm{m}^{-3}$, but some very high values were recorded on weekends prior to Christmas $\left(12.68 \mathrm{ng} \cdot \mathrm{m}^{-3}\right)$ and on the New Year's Day $\left(25.02 \mathrm{ng} \cdot \mathrm{m}^{-3}\right)$. Such a distribution of data causes a strongly overestimation of the average $\mathrm{BaP}$ concentration and also influences the results of the statistical methods. In result, the obtained mean $\mathrm{BaP}$ concentration was about three times higher than that reported for study area by Czempińska and Zarembski (2008). At the same time, such average BaP concentration in aerosols as obtained in this study is still lower than that reported by various authors for this and other areas in Poland (Table 3). Relatively low concentrations of analyzed compound resulted probably from low industrialization of the studied area, relatively small number of 'low emission sources' (in comparison to other Polish cities) and the influence of maritime ("clean") air masses. Concentrations of $\mathrm{BaP}$ lower than these measured in Gdynia were observed in a non-urbanized woody area "Puszcza Borecka" (Table 3). In the other European countries, in strongly urbanized areas (Italy, Hungary) or areas with intensive coal and wood domestic heating (Czech Republic), the average atmospheric $\mathrm{BaP}$ concentrations are comparable or higher than these observed in Gdynia (Table 3).
Fig. 2 Benzo(a)pyrene concentrations in aerosols in Gdynia in subsequent months of the sampling period (17.XII.2007-17.XII.2008)

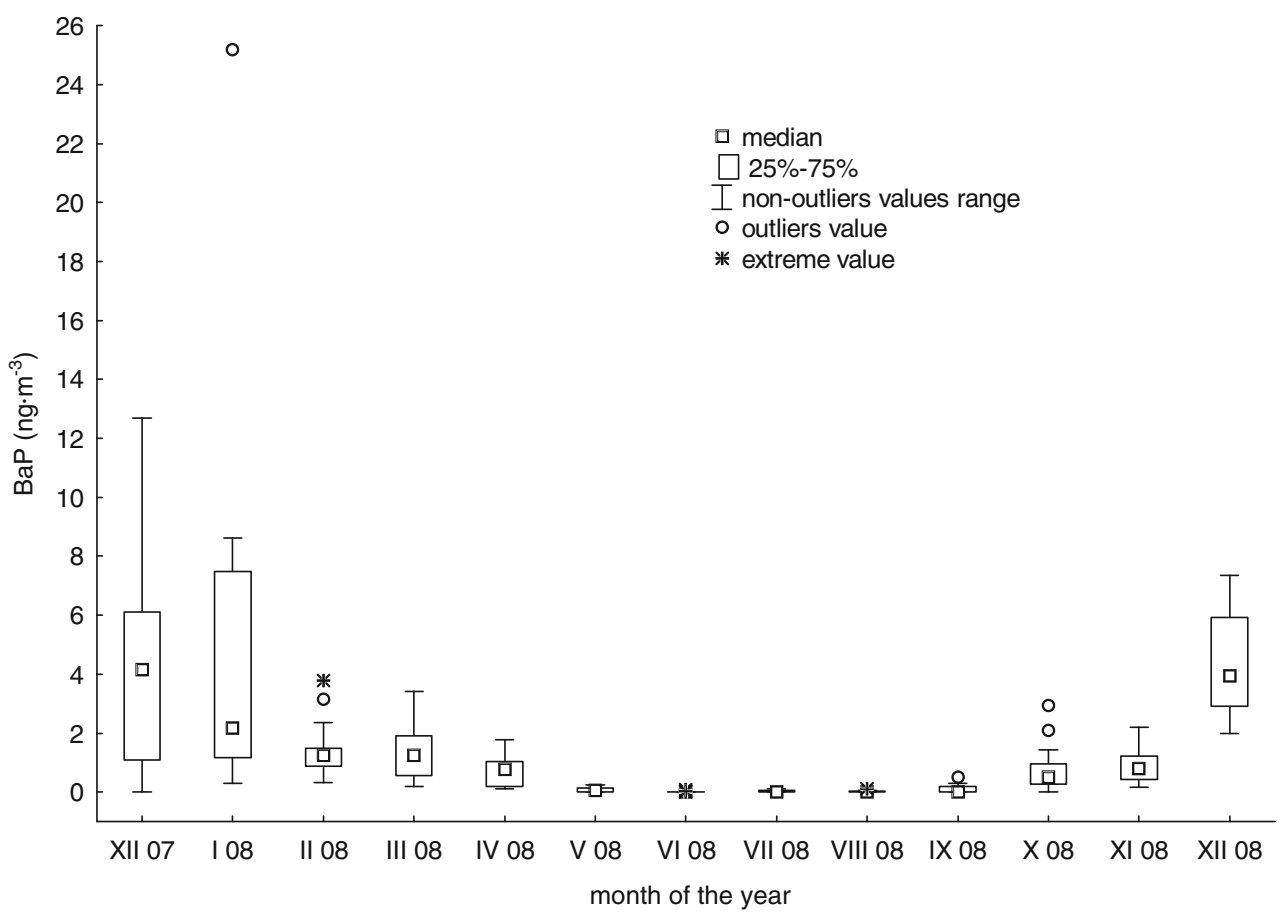


Table 3 The average concentrations of $\mathrm{BaP}\left(\mathrm{ng} \mathrm{m}^{-3}\right)$ in aerosols in selected areas

\begin{tabular}{|c|c|c|c|c|c|}
\hline & City & $\mathrm{BaP}\left(\mathrm{ng} \cdot \mathrm{m}^{-3}\right)$ & Particle size & Remarks & Reference \\
\hline \multirow[t]{11}{*}{ POLAND } & Gdansk-Przeróbka & $3.8 / 0.1^{\mathrm{a}}$ & PM10 & \multirow{3}{*}{$\begin{array}{l}\text { North Poland } \\
\text { (coast of Baltic Sea) }\end{array}$} & Report WSSE (2007) \\
\hline & Gdynia & $\begin{array}{r}2.18 / 0.05^{\mathrm{a}} 1.29 \text { (average from } \\
17 . \text { XII.2007 to } 17 . \text { XII.2008) }\end{array}$ & TSP & & This work \\
\hline & Gdynia & 0.8 (average annual) & PM10 & & $\begin{array}{l}\text { Czempińska and } \\
\text { Zarembski (2008) }\end{array}$ \\
\hline & Wejherowo & $12.1 / 0.9^{\mathrm{a}}$ & PM10 & \multirow[t]{3}{*}{ North Poland (inland) } & \multirow[t]{3}{*}{ Report WSSE (2007) } \\
\hline & Kościerzyna & $9.3 / 0.5^{\mathrm{a}}$ & PM10 & & \\
\hline & Słupsk & $7.3 / 0.6^{\mathrm{a}}$ & PM10 & & \\
\hline & Chorzów & $32.3 / 0.8^{\mathrm{a}}$ & PM10 & \multirow{4}{*}{$\begin{array}{l}\text { South Poland } \\
\text { (industrial field) }\end{array}$} & \multirow[t]{4}{*}{ Report WSSE (2005) } \\
\hline & Gliwice & $28.6 / 0.1^{\mathrm{a}}$ & PM10 & & \\
\hline & Katowice & $20.1 / 1.2^{\mathrm{a}}$ & PM10 & & \\
\hline & Tychy & $36.9 / 1.5^{\mathrm{a}}$ & PM10 & & \\
\hline & Puszcza Borecka & $1.14 / 0.05^{\mathrm{a}}$ & PM10 & $\begin{array}{l}\text { Non-urbanized woody } \\
\text { areas (north-east Poland) }\end{array}$ & Bogucka (2009) \\
\hline \multirow{3}{*}{$\begin{array}{l}\text { OTHER } \\
\text { COUNTRIES } \\
\text { OF THE EU }\end{array}$} & $\begin{array}{l}\text { Prachatice/Teplice } \\
\text { (Czech Republic) }\end{array}$ & $5.50 / 0.51^{\mathrm{a}}$ & TSP & Health-resort & Lenicek et al. (1997) \\
\hline & $\begin{array}{l}\text { Taranto } \\
\text { (Italy) }\end{array}$ & $0.03-65.62 / 0.033-3.55^{\mathrm{a}}$ & PM10 & Urbanized areas & Filippo et al. (2010) \\
\hline & $\begin{array}{l}\text { Keszthely, Tihany, } \\
\text { Siofok } \\
\text { (Hungary) }\end{array}$ & $2.56 / 0.18^{\mathrm{a}}$ & TSP & $\begin{array}{l}\text { Non-urbanized (north part } \\
\text { of the Lake Balaton) }\end{array}$ & $\begin{array}{l}\text { Bodnar and Hlavay } \\
\text { (2005) }\end{array}$ \\
\hline
\end{tabular}

${ }^{\text {a } H e a t i n g / n o n-h e a t i n g ~ s e a s o n ~}$

It should be noted that some BaP concentration, which are presented in Table 3, are referred to PM10. Kubica (2003) suggested that the contribution of particles smaller than $10 \mu \mathrm{m}$ in TSP originating from coal and wood combustion amounts to ca. $70 \%$. According to Lewandowska et al. (2010), the contribution of PM10 to TSP in Gdynia ranged from $35 \%$ to $92 \%$. In addition, most of PAHs concentration might be associated with fine particles (see Intoduction). In a result, concentration of BaP in PM10 is probable equal or smaller then in TPS.

Factors controlling the variability of benzo(a)pyrene concentration in aerosols

\section{Meteorological conditions}

Depending on natural climate conditions different meteorological factors tend to control the BP concentrations in aerosols (Papageorgopoulou et al. 1999; Chetwittayachan et al. 2002; Callen et al. 2008). The principal component analysis of measured meteorological parameters and $\mathrm{BaP}$ concentrations was performed. It distinguished three factors explaining $74 \%$ of data variability. Factor 1, controlling $36 \%$ of observed variability, was correlated with temperature, relative humidity and benzo(a)pyrene concentration. Factor 2 explained $22 \%$ of the variability and was strongly influenced by the wind speed and atmospheric pressure. Factor 3, related to the amount of precipitation, explained
$17 \%$ of variability of the dataset (Table 4). Factor 1 quite clearly separated the concentrations of benzo(a)pyrene measured in the heating and non-heating seasons (Fig. 3). High temperatures, typical for non-heating season, corresponded to low $\mathrm{BaP}$ concentrations, while low temperature, characteristic for heating seasons, corresponded to high $\mathrm{BaP}$ concentrations. The only exceptions (i.e., high concentration of $\mathrm{BaP}$ and high temperature) were observed when relatively high air temperatures $\left(>10{ }^{\circ} \mathrm{C}\right)$ occurred during the heating season. Such a situation happened in October 2008. High $\mathrm{BaP}$ concentrations in heating season probably resulted from an increase in the pollution from domestic heating and 4-10-fold higher emission of exhaust fumes from traffic in winter (Kiss et al. 2001). Such high emission of exhaust fumes is caused by higher fuel consumption in low air temperatures. Furthermore, coal and wood combustion is a

Table 4 Principal component analysis (PCA) factor loadings for meteorological conditions and benzo(a)pyrene concentration in aerosols in Gdynia (17.XII.2007-17.XII.2008)

\begin{tabular}{lrrr}
\hline Variable & Factor 1 & Factor 2 & Factor 3 \\
\hline Amount of precipitation $(\mathrm{mm})$ & -0.23 & -0.02 & $\mathbf{0 . 9 5}$ \\
Wind speed $\left(\mathrm{m} \cdot \mathrm{s}^{-1}\right)$ & -0.44 & $\mathbf{0 . 6 8}$ & 0.14 \\
Relative humidity $(\%)$ & $\mathbf{- 0 . 7 2}$ & -0.11 & -0.05 \\
Atmospheric pressure (mbar) & 0.13 & $\mathbf{- 0 . 8 5}$ & 0.18 \\
Air temperature $\left({ }^{\circ} \mathrm{C}\right)$ & $\mathbf{0 . 9 1}$ & 0.11 & 0.04 \\
$\mathrm{BaP}\left(\mathrm{ng} \cdot \mathrm{m}^{-3}\right)$ & $\mathbf{- 0 . 7 5}$ & -0.29 & -0.24 \\
\hline
\end{tabular}




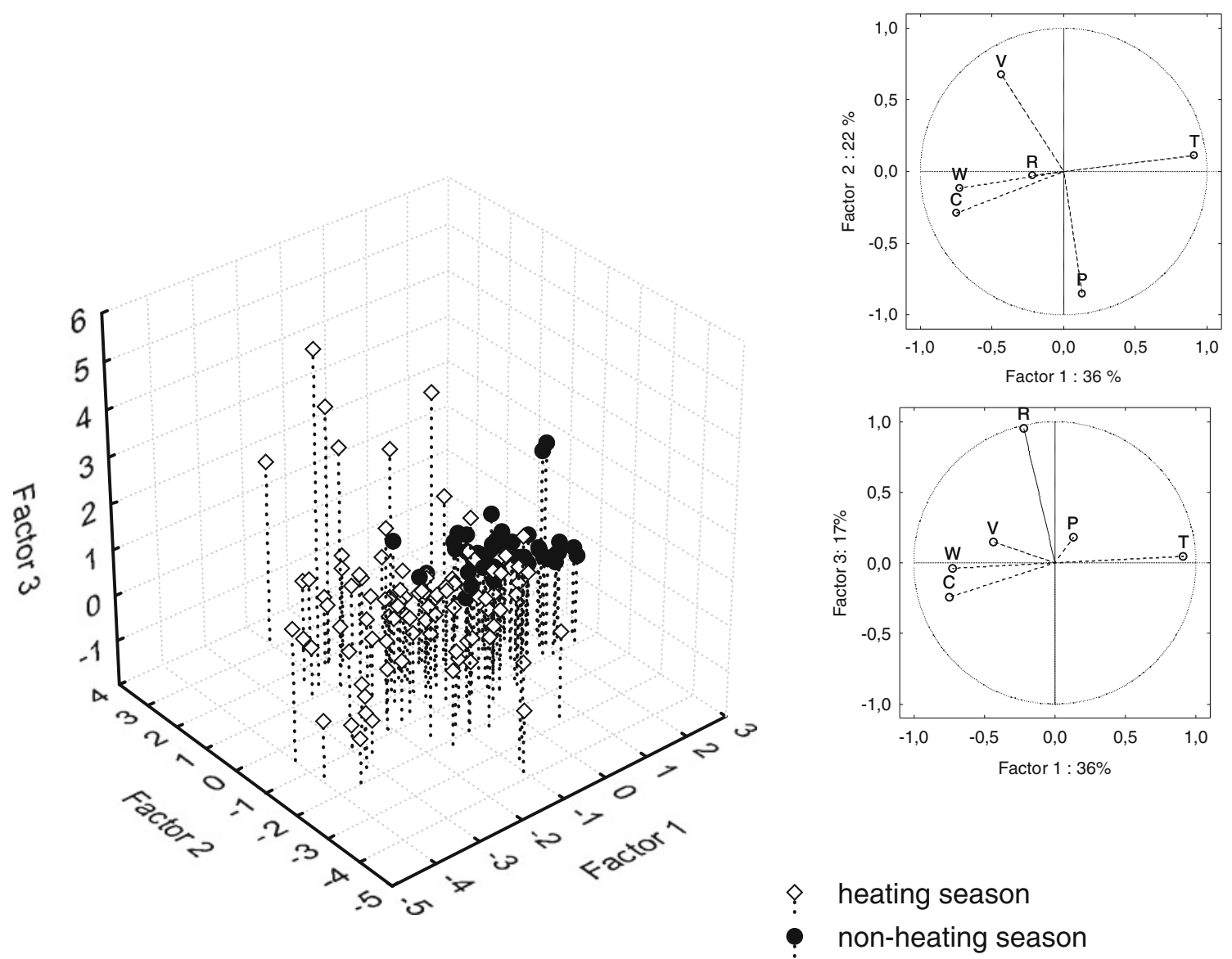

Fig. 3 Factor scores for individual cases of the dataset containing meteorological conditions ( $V$ wind velocity, $R$ amount of precipitation, $T$ air temperature, $P$ atmospheric pressure, $W$

source of soot and fly ash which strongly adsorp BaP. In such form, BaP is more resistant for photooxidation (Ravindra et al. 2008). Low air temperature favors increased benzo(a)pyrene emission to the atmosphere not only in a direct way (heating), but also decreases the vapor pressure of BaP, what increases its affinity to aerosols (Ravindra et al. 2008). Moreover, the low air temperature in winter typically causes lowering of the mixing height what results in increased concentrations of $\mathrm{BaP}$ in the lower layers of the atmosphere. In many studies, thermal degradation caused by solar radiation was also reported to have a significant influence on the BaP removal from the atmosphere in warm months (Chetwittayachan et al. 2002; Tham et al. 2008; Callen et al. 2008). An increase in the concentration of ${ }^{\circ} \mathrm{O}_{3}$ and ${ }^{\circ} \mathrm{OH}$ and ${ }^{\circ} \mathrm{NO}_{2}$ radicals also favors chemical transformations of all PAHs into other compounds, i.e. nitric derivatives (Papageorgopoulou et al. 1999; Park et al. 2002). According to Ravindra et al. (2008), half life time of BaP under laboratory conditions (simulated sun light) equaled $5.3 \mathrm{~h}$, while it was ten times shorter after the addition of ozone, regardless of the irradiance conditions. In a result of the complex nature of processes influencing $\mathrm{BaP}$ relative humidity, $C \mathrm{BaP}$ concentration) and benzo(a)pyrene concentration ( $C \mathrm{BaP}$ concentration) in aerosols in Gdynia (excluding Christmas and New Year's Eve)

concentration in the air, exponentially increased of this constituent with the decrease in the air temperature was observed (Fig. 4).

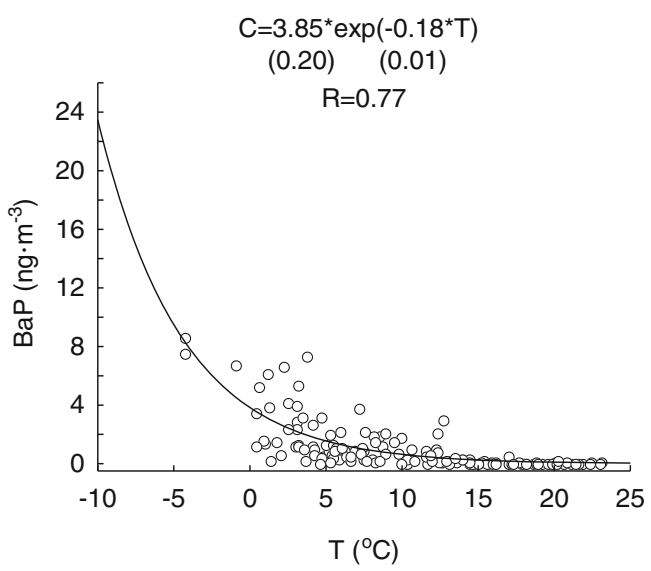

Fig. 4 Relationship between the air temperature $(T)$ and benzo(a) pyrene concentration $(C)$ in aerosols in Gdynia (excluding concentrations of BaP during Christmas and on the New Year's Eve). Standard errors of regression coefficients are given in the brackets (both coefficients were statistically significant, $p=0.00$ ) 
The principal component analysis indicated strong correlation between the air temperature, relative humidity and benzo(a)pyrene concentrations (Table 4). Many studies (Park et al. 2002; Mantis et al. 2005; Callen et al. 2008; Tham et al. 2008) point at relative humidity, beside temperature, as a factor controlling particulate bound PAHs concentration in temperate zones. In order to investigate the influence of both temperature and relative humidity on the benzo(a)pyrene concentrations in the studied area, the cluster analysis was employed. This is an exploratory data analysis tool which encompasses a number of different algorithms and methods for grouping objects of similar kind into respective categories. In other words, cluster analysis divides data into groups (clusters) so that the objects in the same cluster are more similar to each other than to those in other clusters. Thus, cluster analysis discovers structures in data without explaining why they exist (Stanisz 2007; http:// www.statsoft.com/textbook/cluster-analysis/). These techniques have been applied to a wide variety of research problems. Hartigan (1975) provides an excellent summary of the many published studies reporting the results of cluster analyses. In the case of presented data, the cluster analysis with regard to the air temperature and relative humidity has been performed. It distinguished three groups (Fig. 5a). After identification

a)

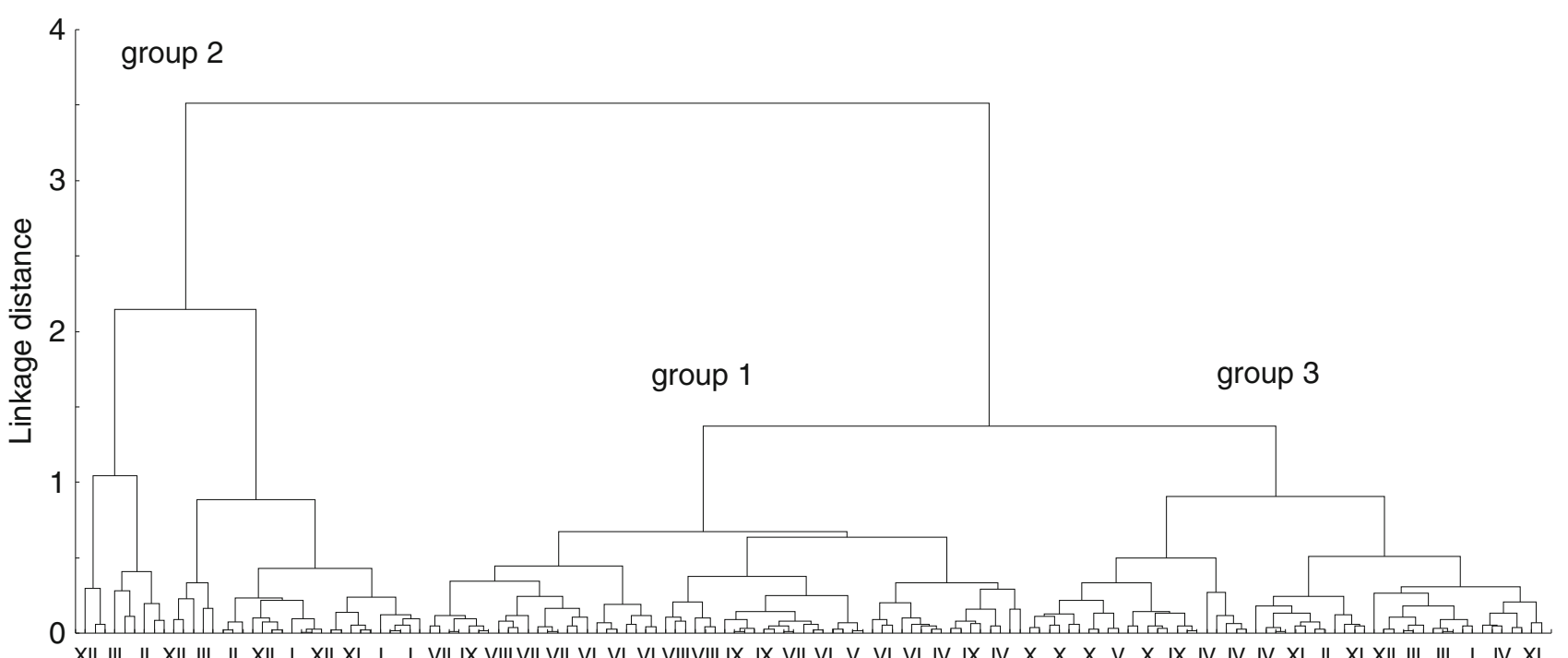

b) $\square$ median: $25 \%-75 \%$ :non-outliers values
range: $\circ$ outliers values

Kruskal-Wallis ANOVA $p=0.000$

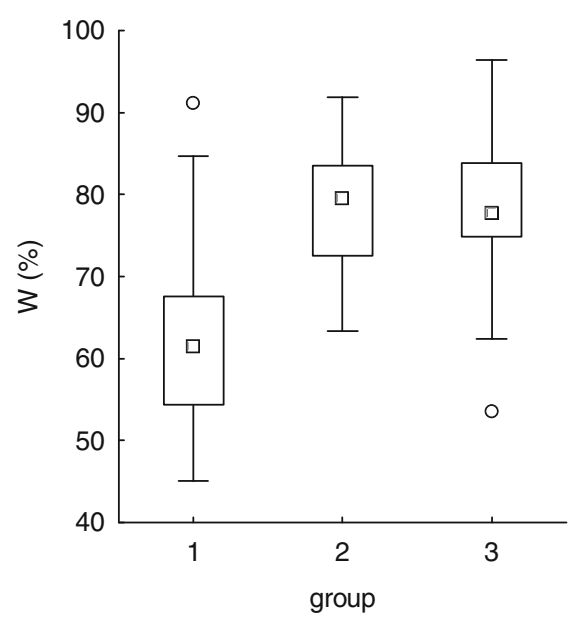

c)

口median: 25\%-75\%: non-outliers values range: $\bigcirc$ outliers values Kruskal-Wallis ANOVA $p=0.000$

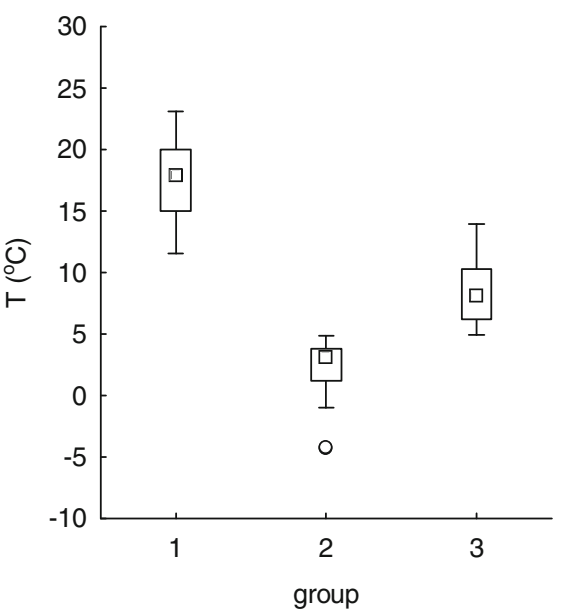

d)

口median: $25 \%-75 \%$ : non-outliers values range: $\bigcirc$ outliers values: * extrime values Kruskal-Wallis ANOVA $p=0.000$

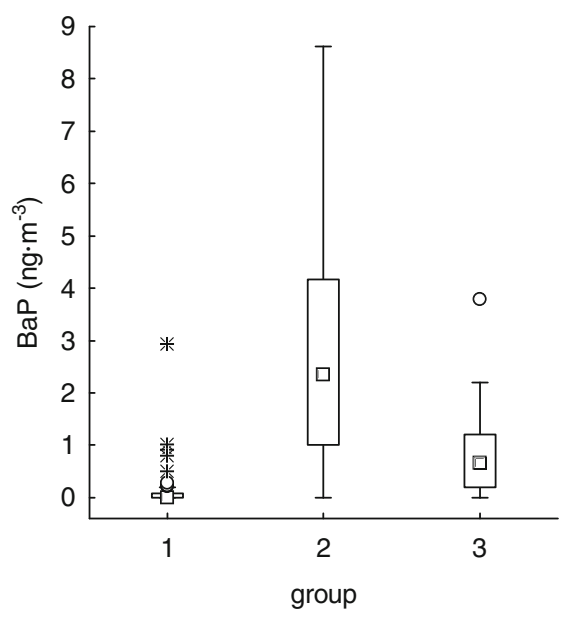

Fig. 5 Cluster analysis results a with regard to the air temperature and relative humidity in Gdynia (17.XII.2007-17.XII.2008), as well as b benzo (a)pyrene concentrations, $\mathbf{c}$ temperature, and $\mathbf{d}$ humidity in groups distinguished by the analysis 


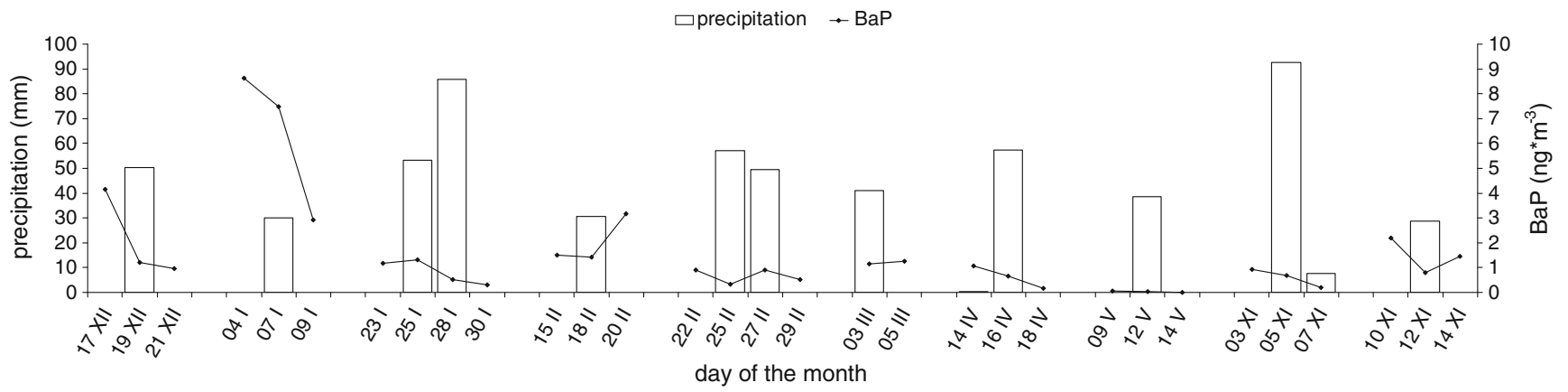

Fig. 6 Concentration of $\mathrm{BaP}$ and the amount of precipitation in selected cases (samples taken before, during and after an intense precipitation event)

which data belong to each groups, significant differences between them have been found (Kruskal-Wallis ANOVA; Fig. 5b, c). Also the concentrations of BaP (Fig. 5d) in these groups were significantly different (Kruskall-Wallis ANOVA; Fig.5d). Relatively high concentration of this parameter was noted in groups 3 and 2 which were characterized by high humidity and low temperature (Fig. 5b, c). Many aforementioned interplaying processes favor high concentrations of $\mathrm{BaP}$ during low air temperature periods. In the case of humidity, higher values of this parameter favors the creation of larger aggregates, which are not transported over large distances, and in majority contribute to the air pollution close to an emitter (Chetwittayachan et al. 2002; Bełdowska et al. 2012; Ravindra et al. 2008). Moreover, low temperature together with high humidity cause a decrease in the wind chill temperature, what can result in more intensive residential heating and therefore increased $\mathrm{BaP}$ emission.

The studies conducted in tropical regions (Thornhill et al. 2008) indicated the major influence of precipitation on the $\mathrm{BaP}$ concentration. High levels of precipitation causing particle removal by washout are one of the factors responsible for reducing the ambient $\mathrm{BaP}$ concentration. In the studied area precipitation higher than $28.6 \mathrm{~mm}$ in most cases caused the decrease in the $\mathrm{BaP}$ concentration in samples collected during and/or after the rainfall event (Fig. 6).

\section{Air masses backward trajectory}

During the heating season, the results of the backward trajectory analysis were consistent with the known location of the BaP source. The continental air masses (S, SE, SW sectors) were affected by the heating contaminations and therefore characterized by higher average $\mathrm{BaP}$ levels $\left(2.86 \mathrm{ng} \mathrm{m}^{-3}\right)$ in comparison to these observed in the maritime air masses (N, NE, NW sectors) for which the average $\mathrm{BaP}$ concentration was $1.27 \mathrm{ng} \mathrm{m}^{-3}$.

The impact of the air masses trajectory on the BaP concentration was particularly visible during periods of high concentration of this component in December 2007-January 2008. When the trajectory of the air masses changed from NE (Fig. 7a) to SW (Fig. 7b) and the air was coming from over the land on 22-24.XII.2007, the BaP concentration raised from 0.99 to $12.68 \mathrm{ng} \mathrm{m}^{-3}$ and remained elevated to
NOAA HYSPLIT MODEL
a) Backward trajectories ending at 12 UTC 20 Dec 07

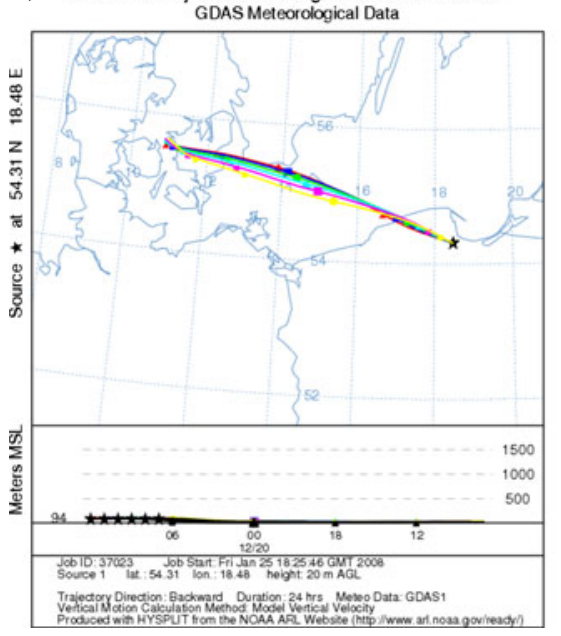

NOAA HYSPLIT MODEL
b) Backward trajectories ending at 12 U

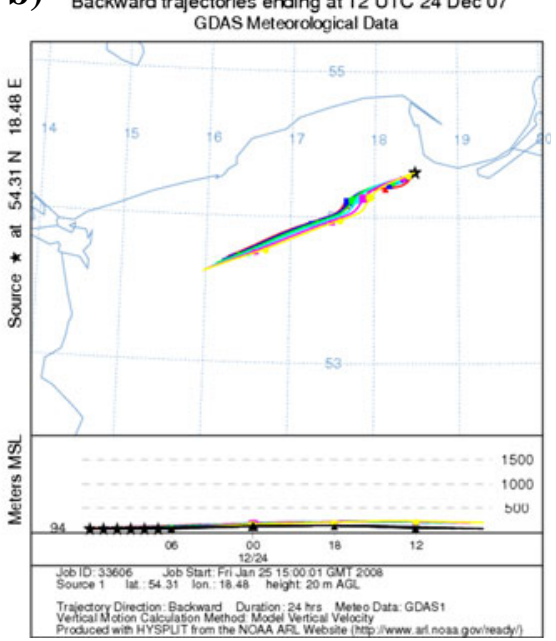

C) NOAA HYSPLIT MODEL
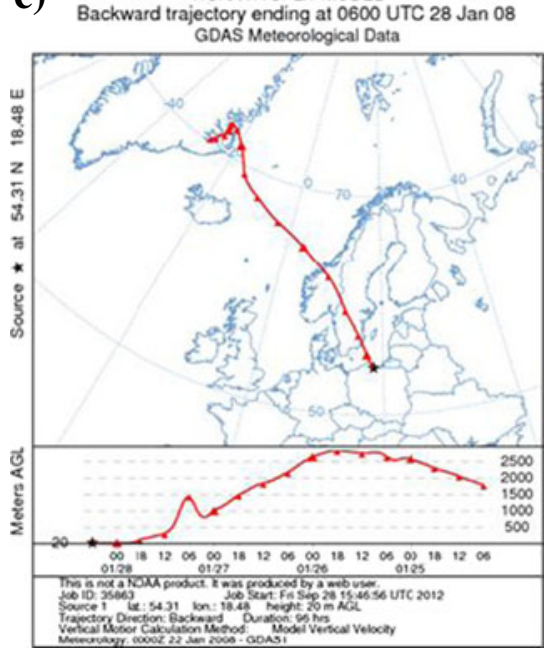

Fig. 7 Change of the backward trajectories of air masses during the time when low (a 20-21.XII.2007; c 28-30.I.2008) and high (b 2224.XII.2007) BaP concentrations were observed 
25.I.2008 (up to $25.20 \mathrm{ng} \mathrm{m}^{-3}$ ). The mean wind speed in mentioned period of high BaP concentration (22.XII.200725.I.2008) was changeable (from 0 to $5 \mathrm{~m} \mathrm{~s}^{-1}$ ) suggesting both local and regional sources of pollution. At the end of January 2008 the concentrations of BaP decreased again below $0.50 \mathrm{ng} \mathrm{m}^{-3}$. It resulted from the influence of the incoming "clean" maritime air masses of high wind speed $\left(3-5 \mathrm{~m} \mathrm{~s}^{-1}\right.$; Fig. 7c). In addition, the daily average temperatures during the periods of high $\mathrm{BaP}$ concentration were lower (rang from $-4{ }^{\circ} \mathrm{C}$ to $+6{ }^{\circ} \mathrm{C}$ ) compared to the temperature during the period of small $\mathrm{BaP}$ concentrations (range from $+3{ }^{\circ} \mathrm{C}$ to $+6{ }^{\circ} \mathrm{C}$ ). Consequently, the observed variability of $\mathrm{BaP}$ content could be partly connected to the fluctuation of the temperature.

During non-heating season, the cleansing effect of the maritime air masses on atmosphere pollution has not been observed. This may suggest that domestic heating significantly contributed to the atmosphere pollution by $\mathrm{BaP}$ at the sampling site.

\section{Short-time variability of benzo(a)pyrene concentration of aerosols}

In urban areas high automobile traffic potentially enhances the emission of $\mathrm{BaP}$ during working days compared to weekends. In turn, in the heating season higher emission might be expected when people stay at home longer as a result of more intensive residential combustion. In the studied area, the differences between the benzo(a)pyrene concentrations in aerosols on working and non-working days were investigated in three ways - for the whole set of data, as well as for heating and non-heating season separately. The analysis of the entire data set revealed that the $\mathrm{BaP}$ levels were approximately twice higher on non-working days, however, the difference was not statistically significant (Mann-Whitney $U$ test, $p=0.19$; Table 2). Significant differences between $\mathrm{BaP}$ concentrations on working and non-working days were observed during the heating season (Mann-Whitney $U$ test, $p=$ 0.04). However, the observed differences were caused mostly by very high benzo(a)pyrene concentrations measured in weekends prior to Christmas 2007-12.68 $\mathrm{ng} \mathrm{m}^{-3}$ and in New Year 2007/2008-25.02 $\mathrm{ng} \mathrm{m}^{-3}$. After excluding these values, the differences were not statistically significant ( $U$ test, $p=0.11$ ). Considerable diversity in the $\mathrm{BaP}$ concentrations noted during working and non-working days was observed also in non-heating season (Mann-Whitney $U$ test, $p=0.04$ ). Weekends at this season were characterized by higher frequency of large $\mathrm{BaP}$ concentrations compared to these noted on working days. Such a trend results from including May and September into the non-heating season. The air temperature during these months can be relatively low which in some cases causes enhanced domestic heating. During the study period $75 \%$ of the temperature values measured in May and September were below $16{ }^{\circ} \mathrm{C}$. After excluding May and
September from the non-heating season, the differences between working and non-working days became insignificant (Mann-Whitney $U$ test, $p=0.22$ ).

\section{Conclusions}

The average annual concentrations of $\mathrm{BaP}$ in aerosols in the urbanized coastal zone of the Gulf of Gdansk (1.29 $\left.\mathrm{ng} \mathrm{m}^{-3}\right)$ were lower than these observed in other urbanized and affected by intensive coal and wood domestic heating areas in Poland and in European countries. At the same time the obtained concentration exceeded the acceptable for EU countries (Directive 2004/107/WE) annual average value $\left(1 \mathrm{ng} \mathrm{m}^{-3}\right)$.

Combustion processes, especially domestic heating of both local and regional origin, were identified as the main sources of benzo(a)pyrene in study area. As a result, $\mathrm{BaP}$ concentrations during the heating season were significantly higher than those observed in the non-heating season. Strong seasonal variability suggests that the establishing of monthly acceptable level of concentration of benzo(a)pyrene would be valuable.

$\mathrm{BaP}$ concentrations in aerosols in the studied area are clearly dependent on the air temperature and relative humidity. Low temperature and large relative humidity favor high concentration of $\mathrm{BaP}$ in aerosols, whereas precipitation higher than $28.6 \mathrm{~mm}$ usually decreases the $\mathrm{BaP}$ concentration in aerosols.

Wind direction and air masses trajectories play a major role in determining the $\mathrm{BaP}$ concentrations in aerosols in the studied area during the heating season. Continental air masses $(\mathrm{S}$, $\mathrm{SE}$, and $\mathrm{SW}$ ) increase the $\mathrm{BaP}$ concentrations, while maritime air masses coming from over the Baltic Sea (N, NE, NW) cause the decrease in the concentration of this compound.

The differences in the $\mathrm{BaP}$ concentration resulting from potentially different emission levels of this compound during working and non-working days were not clearly pronounced. For the non-heating season it results from the artificial division of the study period into heating and nonheating season. Whereas for the heating season it is caused by some incidental very high $\mathrm{BaP}$ concentrations noted at the turn of December and January as well as during the Christmas season. This problem requires further study.

Open Access This article is distributed under the terms of the Creative Commons Attribution License which permits any use, distribution, and reproduction in any medium, provided the original author(s) and the source are credited.

\section{References}

Bełdowska M, Saniewska D, Falkowska L, Lewandowska A (2012) Mercury in particulate matter over Polish zone of the southern Baltic Sea. Atmos Environ 46:397-404 
Bodnar E, Hlavay J (2005) Atmospheric deposition of polycyclic aromatic hydrocarbons on the Lake Balaton, Hungary. Microc J 79:213-220

Bogucka M (2009) Monitoring of background air pollution in Poland for the EMEP and GAW/WMO 2008. Report GIOŚ, Warsaw, p 51, in Polish

Callen M, de la Cruz M, Lopez J, Murillo R, Navarro M, Mastral A (2008) Long-range atmospheric transport and local pollution sources on PAH concentrations in a South European urban area. Fulfilling of the European directive. Water Air Soil Pollut 190:271-285

Chetwittayachan T, Shimazaki D, Yamamoto K (2002) A comparison of temporal variation of particle-bound polycyclic aromatic hydrocarbons (pPAHs) concentration in different urban environments: Tokyo, Japan, and Bangkok, Thailand. Atmos Environ 36:2027-2037

Czempińska A, Zarembski A (2008) Annual assessment of air quality in the Pomorskie District in 2007 year. WIOŚ, Gdansk, p 45, In Polish

Fabiani R, De Bartolomeo A, Rosignoli P, Morozzi G, Cecinato A, Balducci C (2008) Chemical and toxicological characterization of airborne total suspended particulate (TSP) and PM10 organic extracts. Polycycl Aromat Comp 28:486-499

Filippo P, Riccardi C, Pomata D, Gariazzo C, Buiarelli F (2010) Seasonal abundance of particle-phase organic pollutants in an urban/industrial atmosphere. Water Air Soil Pollut 211:231-250

Halek F, Nabi G, Ganjidoust, Keyanpour M, Mirmohammadi M (2006) Particulate polycyclic aromatoc hydrocarbons in urban air of Teheran. Iran J Environ Health Aci Eng 3:247-254

Hartigan JA (1975) Clustering algorithms. Willey, New York

Ji H, Zang D, Shinohara R (2007) Size distribution undestimated carcinogenic potential of particulate polycyclic aromatic hydrocarbonscollected at a downtown site in Kumamoto Japan in Spring. J Health Sci 53:700-707

Jung KH, Yan B, Chillrud S, Perera F, Whyatt R, Camann D, Kinney P, Miller R (2010) Assessment of benzo(a)pyrene-equivalent carcinogenicity and mutagenicity of residential indoor versus outdoor polycyclic aromatic hydrocarbons exposing young children in New York City. Int J Environ Res Public Health 7:1889-1900

Kiss G, Varga-Puchony Z, Tolnai B, Varga B, Gelencser A, Krivacsy Z, Hlavay J (2001) The seasonal changes in the concentration of polycyclic aromatic hydrocarbons in precipitation and aerosol near Lake Balaton, Hungary. Environ Pollut 114:55-61

Kubica K (2003) Termochemical processing of coal and biomass. IChPW and IGSMiE publishing, Zabrze-Krakow, p 232, in Polish. ISBN 83-913434-1-3

Lenicek J, Sekyra M, Pandey P, Citkova M, Benes I, Novotna J, Kocianova S, Helaskova J, Simonova A (1997) Polycyclic aromatic hydrocarbons at "Program Teplice" sites in the Czech Republic. Toxicol Environ Chem 58:25-30

Lewandowska A, Falkowska L, Murawiec D, Pryputniewicz D, Burska D, Bełdowska M (2010) Elemental and organic carbon in aerosols over urbanized coastal region (southern Baltic Sea, Gdynia). Sci Total Environ 408:4761-4769

Mantis J, Chaloulakou A, Samara C (2005) PM 10-bound polycyclic aromatic hydrocarbons (PAHs) in the Greater Area of Athens, Greece. Chemosphere 59:593-604

Nielsen T, Jorgensen HE, Larsen JC, Polusen M (1996) City air pollution of pollution of polycyclic aromatic hydrocarbons and other mutagens: occurrence, sources and health effect. Sci Total Environ 189(190):41-49

Papageorgopoulou A, Manoli E, Touloumi, Samara C (1999) Polycyclic aromatic hydrocarbons in the ambient air of Greek towns in relation to other atmospheric pollutants. Chemosphere 39:2183-2199

Park S, Kim Y, Kang C (2002) Atmospheric polycyclic aromatic hydrocarbons in Seoul, Korea. Atmos Environ 36:2917-292

Periera P, Andrade J, Miguel A (2001) Determination of 16 priority polycyclic aromatic hydrocarbons in particulate matter by HRGCMS after extraction by sonication. Anal Sci 17:1229-1231

Ravindra K, Sokhi R, Van Grieken R (2008) Atmospheric polycyclic aromatic hydrocarbons: source attribution, emission factors and regulation. Atmos Environ 42:2895-2921

Report WSSE (2005) Atmospheric pollution in the Silesia District in 2003-2004. WSSE, Katowice (In Polish)

Report WSSE (2007) Evaluation of the state sanitary and epidemiological situation in the Pomorskie District in 2006 year. PIS, WSSE, Gdansk, p 210, In Polish

Sheu H, Lee W, Lin S, Fang G, Chang H, You W (1997) Particlebound PAH content in ambient air. Environ Pollut 96:369-382

Stanisz A (2007) Przystępny kurs statystyki z zastosowaniem STATISTICA PL na przykładach z medycyny. Tom 3. Analizy wielowymiarowe, (The use of STATISTICA PL Vol. 3 Multivariate analysis). StatSoft Polska, Kraków, p 500, In Polish Statistical yearbook (2008) GUS, Warszawa, 888 p. (In Polish)

Szymanska K (ed.), Bielawska M, Kachniarz E, Kolakowski T, Sarafin M, Waszczyk T (2008) State of atmospheric air pollution in agglomeration of Gdansk and Tczew in 2008, information about the foundation ARMAAG, Report ARMAAG, 69 p. (In Polish)

Tao S, Wang Y, Wu S, Liu S, Dou H, Liu Y, Lang CH, Hu F, Xing B (2007) Vertical distribution of polycyclic aromatic hydrocarbons in atmospheric boundary layer of Beijing in winter. Atmos Environ 41:432-447

Tham Y, Takeda K, Sakugawa H (2008) Polycyclic aromatic hydrocarbons (PAHs) associated with atmospheric particles in Higashi Hiroshima, Japan: influence of meteorological conditions and seasonal variations. Atmos Res 88:224-233

Thornhill D, de Foy B, Herndon S, Onasch T, Wood E, Zavala M, Molina L, Gaffney J, Marley N, Marr L (2008) Spatial and temporal variability of particulate polycyclic aromatic hydrocarbons in Mexico City. Atmos Chem Phys 8:3093-3105

Zhou J, Wang T, Huang Y, Mao T, Zhong N (2005) Size distribution of polycyclic aromatic hydrocarbons in urban and suburban sites of Beijing, China. Chemosphere 61:792-799 